\title{
Antioxidative Effects of a Processed Grain Food
}

\author{
Yukiko MinamiYama, ${ }^{1}$ Toshikazu Yoshikawa, ${ }^{1,2}$ Toru Tanigawa, ${ }^{1}$ \\ Syuji TAKahashi, ${ }^{1}$ Yuji NaIto, ${ }^{1}$ Hiroshi IchIKawa, ${ }^{1}$ \\ and Motoharu KoNDO ${ }^{1}$ \\ ${ }^{1}$ First Department of Internal Medicine, Kyoto Prefectural \\ University of Medicine, Kamigyo-ku, \\ Kyoto 602, Japan \\ ${ }^{2}$ Research Center for Advanced Science and Technology, \\ The University of Tokyo, Meguro-ku, \\ Tokyo 153, Japan
}

(Received April 5, 1994)

Summary $\quad$ Antioxidant biofactor: $\mathrm{AOB}^{\circledR}$ is a unique processed grain food. It is a yellow-green powder. It contains the following extracts: germ extracts, soybean, rice bran, tear grass, sesame, wheat, citron, green tea, green leaf extract, and malted rice. These materials were slowly roasted under a powdered oure at less than $60^{\circ} \mathrm{C}$ and fermented with Aspergillus oryzae over 3 days to transform each ingredient into low molecular weight substances. These conditions were different by each material, environmental humidity and temperature. It probably contains a variety of substances having antioxidant activity including flavonoids, $\alpha$-tocopherol, vitamin $\mathrm{C}$, and tannins. We investigated its antioxidative properties using electron spin resonance (ESR) and autoxidation of rat brain homogenates. The superoxide, hydroxyl radical, and the stable free radical, diphenyl-p-picrylhydrazyl (DPPH) radical scavenging activity of $\mathrm{AOB}^{\circledR}$ was investigated using ESR spectrometry. In an in vitro study, a suspension of $\mathrm{AOB}^{\circledR}$ was added directly to a superoxide generating system (hypoxanthine-xanthine oxidase; $\mathrm{HX} / \mathrm{XO}$ ) and investigated using 5,5dimethyl-1-pyrroline- $N$-oxide (DMPO) as a spin trapping agent. At final concentrations of $0.01,0.05$, and $0.1 \mathrm{mg} / \mathrm{ml}, \mathrm{AOB}^{\circledR}$ dose-dependent scavenging activity was observed as $0.103,0.619$, and $1.369 \mathrm{U} / \mathrm{ml}$, respectively. A concentration of $1.0 \mathrm{mg} / \mathrm{ml}$ completely scavenged DMPO-OOH signals; $1.0 \mathrm{mg} / \mathrm{ml}$ of $\mathrm{AOB}^{\circledR}$ inhibited the DMPO-OH signal generated by Fenton's reaction, but its inhibitory effect was not competitive, and was inhibition of the Fenton's reaction. $1.0,3.0$, and $5.0 \mathrm{mg} / \mathrm{ml}$ of $\mathrm{AOB}^{\circledR}$ were significantly inhibited the DPPH radical. In an in vivo study, rats were fed $\mathrm{AOB}^{\circledR}$ orally at doses of 1 or $5 \mathrm{~g}$ /day for $24 \mathrm{~h}$ or for 3 days and the superoxide scavenging activity was measured in plasma. With the administration of $1 \mathrm{~g} /$ day for 3 days, the superoxide scavenging activity was 
about 1.8 times that of the control group fed a basal diet; 1.5 times the control with $5 \mathrm{~g} /$ day for 1 day, and 2.6 times the control with $5 \mathrm{~g} /$ day for 3 days, all of which represented significant increases in superoxide scavenging activity. $\mathrm{AOB}^{\circledR}$ strongly inhibited the autoxidation of rat brain homogenates in vitro in a dose-dependent manner. However, each ingredient before roast and fermentation little inhibited lipid peroxidation. Roasting and fermentation with $A$. oryzae way be important to transform each ingredient into low molecular weight substances. Therefore, it was suggested that $A O B^{\circledR}$ possesses strong antioxidant and free radical scavenging activities.

Key Words antioxidant, food, free radical, ESR, lipid peroxidation

In recent years, it has been reported that numerous pathologic conditions are produced by active oxygen radicals including superoxide and other species (1-14). Thus, their elimination would improve the patient's condition. There has also been a rapid expansion of research on the role of free radicals and antioxidants in the major chronic diseases which afflict mankind (i.e. cancer, cardiovascular disease, and autoimmune disease). Substances with antioxidant activity have also been discovered in food (15). There are also some indications that not only endogenous antioxidants but also dietary antioxidants may be effective in protection from peroxidative damage in living systems. However, quite a few dietary antioxidants have been evaluated using in vivo and in vitro lipid peroxidation systems (16). For this reason, research has begun for novel antioxidants from natural resources, in particular, plant foods, because dietary antioxidants other than $\alpha$-tocopherol may also play an important role in protecting the cell against damage caused by active oxygens and free radicals, and also may have the potential of inhibiting mutagenicity induced during lipid peroxidation (17). Thus, the main function of antioxidant nutrients in an appropriate diet may be the prevention of oxidative damage to cells and physiological functions.

Antioxidant biofactor $\left(\mathrm{AOB}^{\circledR}\right)$ is a processed grain food that contains a mixture which is shown in Table 1. These ingredients are transformed to low molecular weight substances by roasting and fermentation with Aspergillus oryzae. It probably contains a variety of substances having antioxidant activity including flavonoids, $\alpha$-tocopherol, vitamin C, tannins, and vitamin $\mathbf{B}_{2}$. It is possible that these ingredients directly quench reactive, damaging free radicals. We determined the superoxide or hydroxyl radical or DPPH radical scavenging activity of AOB $^{\circledR}$ and its inhibitory effect on autoxidation in rat brain homogenate.

\section{MATERIALS AND METHODS}

The following were used as reagents: hypoxanthine, diethylene triaminepentaacetic acid (DETAPAC), carboxymethyl cellulose sodium salt (CMC), diphenyl-p- 
Table 1. The ingredients of antioxidant biofactor $\left(\mathrm{AOB}^{\circledR}\right)$.

\begin{tabular}{lc}
\hline Rice which still has the germ & $18.0 \%$ \\
Wheat & $9.0 \%$ \\
Wheat germ & $7.5 \%$ \\
Rice bran & $15.0 \%$ \\
Sesame & $4.0 \%$ \\
Adlay & $7.5 \%$ \\
Green tea powder & $9.0 \%$ \\
Green vegetables & $1.0 \%$ \\
Soy-bean & $20 \%$ \\
Citron-juice & $2.5 \%$ \\
Yeast & $6.5 \%$ \\
\hline Total & $100 \%$ \\
\hline
\end{tabular}

picrylhydrazyl (DPPH), $d l$ - $\alpha$-tocopherol, ascorbic acid from Wako Pure Chemical Industries Ltd. (Osaka), xanthine oxidase (grade I) from Sigma (St. Louis, MO), and 5,5-dimethyl-1-pyrroline- $N$-oxide (DMPO) from Daiichi Chemical Co., Ltd. (Tokyo). Human recombinant superoxide dismutase (SOD) was provided by Nippon Kayaku Co., Ltd. (Tokyo). AOB ${ }^{\circledR}$ was provided by AOA Japan Co., Ltd. (Kobe).

$\mathrm{AOB}^{\circledR}$ was used as a suspension in $0.5 \% \mathrm{CMC}$. As a control solution, we used $0.5 \%$ CMC. The superoxide scavenging activity of $\mathbf{A O B}^{\circledR}$ was measured at final concentrations of $0.01,0.05,0.1$, and $1.0 \mathrm{mg} / \mathrm{ml}$. Hydroxyl radical scavenging activity of $\mathrm{AOB}^{\circledR}{ }^{\circledR}$ was measured at final concentrations of $1.0 \mathrm{mg} / \mathrm{ml}$. DPPH radical scavenging activity of $\mathrm{AOB}^{\circledR}$ was used at final concentrations of 1.0, 3.0, and 5.0 $\mathrm{mg} / \mathrm{ml}$. In vivo study, male Sprague-Dawley rats (body weight: 200-220 g; Clea Japan Co., Tokyo) were used. AOB $^{\circledR}$ was given for 1 day or 3 days. In the 1-day experiment, each rat was housed in a separated cage and a dose of $\mathrm{AOB}^{\circledR}, 1$ or 5 $\mathrm{g}$, was mixed with their basal diet (total diet: $15 \mathrm{~g}$; MF Oriental Yeast, Tokyo). Animals were allowed to eat and drink tap water for $24 \mathrm{~h}$ ad libitum. At $24 \mathrm{~h}$, after confirming that the rats had eaten all the food, blood was sampled from the abdominal aorta under pentobarbital anesthesia $(50 \mathrm{mg} / \mathrm{kg}$, i.p.) using syringes containing heparin. Plasma was prepared by centrifugation at $0^{\circ} \mathrm{C}$. The control group was allowed to eat freely the same amount of basal diet, and plasma was similarly collected. Plasma was stored chilled on ice until assayed by ESR for superoxide scavenging activity. In the second experiment, the animals were allowed to feed for 3 days as described in the 1-day experiment, and plasma was assayed for superoxide scavenging activity. Measurements of ESR study were made using a JEOL-JES-FR80 ESR Spectrometer (JEOL Co., Ltd., Tokyo) using a flat quartz ESR cell. The conditions were as follows: magnetic field $335.7 \mathrm{mT}$, microwave power $8.0 \mathrm{~mW}$, modulation frequency $100 \mathrm{kHz}$, modulation amplitude $0.1 \mathrm{mT}$, sweep width $5.0 \mathrm{mT}$, sweep time $10 \mathrm{mT} / \mathrm{min}$, response time $0.03 \mathrm{~s}$, receiver gain $\times 1,000$. 
1) Superoxide (DMPO-OOH) scavenging activity. Under the conditions described, we added $20 \mu \mathrm{l}$ each of $1 \mathrm{mM}$ hypoxanthine, $1 \mathrm{M}$ DTPA, $1 \mathrm{M}$ DMPO, and the sample to $100 \mu 1$ of $100 \mathrm{~mm}$ phosphate buffered saline (PBS; pH 7.4). A volume of $20 \mu \mathrm{l}$ of $0.8 \mathrm{U} / \mathrm{ml}$ xanthine oxidase was added, was placed in the ESR instrument, and measurement was begun in exactly $1 \mathrm{~min}$. Intensity of the DMPO-OOH signal was measured relative to that of an $\mathrm{MnO}$ signal, the internal standard. A standard solution of SOD $(10 \mathrm{U} / \mathrm{ml})$ was substituted for the sample to obtain a calibration curve, and the relationship to the activity units $(0.1,0.5,1.0 \mathrm{U} / \mathrm{ml})$ was determined. The plasma samples used for testing were diluted 12-fold in phosphate-buffered saline.

2) Hydroxyl radical (DMPO-OH) scavenging activity. Hydroxyl radical was produced from Fenton's reaction ( $\mathrm{Fe}^{2+}$ and hydrogen peroxide). Produced hydroxyl radicals were trapped by DMPO. The reaction mixture contained $100 \mu 1$ of $100 \mathrm{~mm}$ PBS (pH 7.4), $200 \mu \mathrm{M}$ DTPA, and $30 \mu 1$ of $1 / 3 \mathrm{mM} \mathrm{FeSO}_{4}$, and $20 \mu \mathrm{l}$ of 0.1 or $1 \mathrm{M}$ DMPO and sample. Then, $30 \mu \mathrm{l}$ of $\mathrm{H}_{2} \mathrm{O}_{2}$ (final conc. $1 \mathrm{mM}$ ) was added to the reaction mixture and measured after 1 min using ESR spectrometer. ESR conditions were the same as described above except for the microwave power (6.0 $\mathrm{mW}$ ). The second DMPO-OH signal intensities were measured relative to an $\mathrm{MnO}$ signal. As a standard solution, $1 \mathrm{M}$ of dimethyl sulfoxide (DMSO) indicated 1 U/liter.

3) The reduction of DPPH radical. The stable free radical DPPH $(100 \mu \mathrm{M})$ was dissolved in 100\% ethanol. Reaction mixture consists of DPPH $(200 \mu \mathrm{l})$ and AOB $^{\circledR}(20 \mu 1)$. DPPH radical was measured after 1,3 , or 5 min at room temperature using an ESR spectrometer. Measurement condition and signal intensity were described above.

Brain tissues were obtained from Sprague-Dawley rats that weigh $200 \mathrm{~g}$. Rats were anesthetized with sodium pentobarbital ( $50 \mathrm{mg} / \mathrm{kg}$, i.p.). Blood was taken via the abdominal aorta, and $50 \mathrm{ml}$ saline were perfused via the same position to remove the blood completely. As soon as possible, the brain tissue was removed and put into iced cold phosphate-buffered saline (PBS, pH 7.4) until homogenization. Brain tissue was homogenized in $0.01 \mathrm{M}$ PBS ( $\mathrm{pH} 7.4$ ). To induce autoxidation, the $5 \%$ homogenate was incubated at $37^{\circ} \mathrm{C}$ in the presence or absence $\mathrm{AOB}^{\circledR}$. $\mathrm{AOB}^{\circledR}$ was suspended in $0.5 \% \mathrm{CMC}$. Lipid peroxides produced by autoxidation were monitored by thiobarbituric acid-reactive substances (TBARS) determined by the method of Ohkawa et al. (18). Data are represented as Mean \pm SEM. Comparisons of data utilized the Mann-Whitney $U$-test, with $p<0.05$ accepted as statistically significant.

\section{RESULTS}

Effect of $A O B^{\circledR}$ on ESR study

Superoxide scavenging activity was measured after adding a suspension of $\mathrm{AOB}^{\circledR}$. At final concentrations of $\mathrm{AOB}^{\circledR}$ of $0.01,0.05$, and $0.1 \mathrm{mg} / \mathrm{ml}$, a marked, 


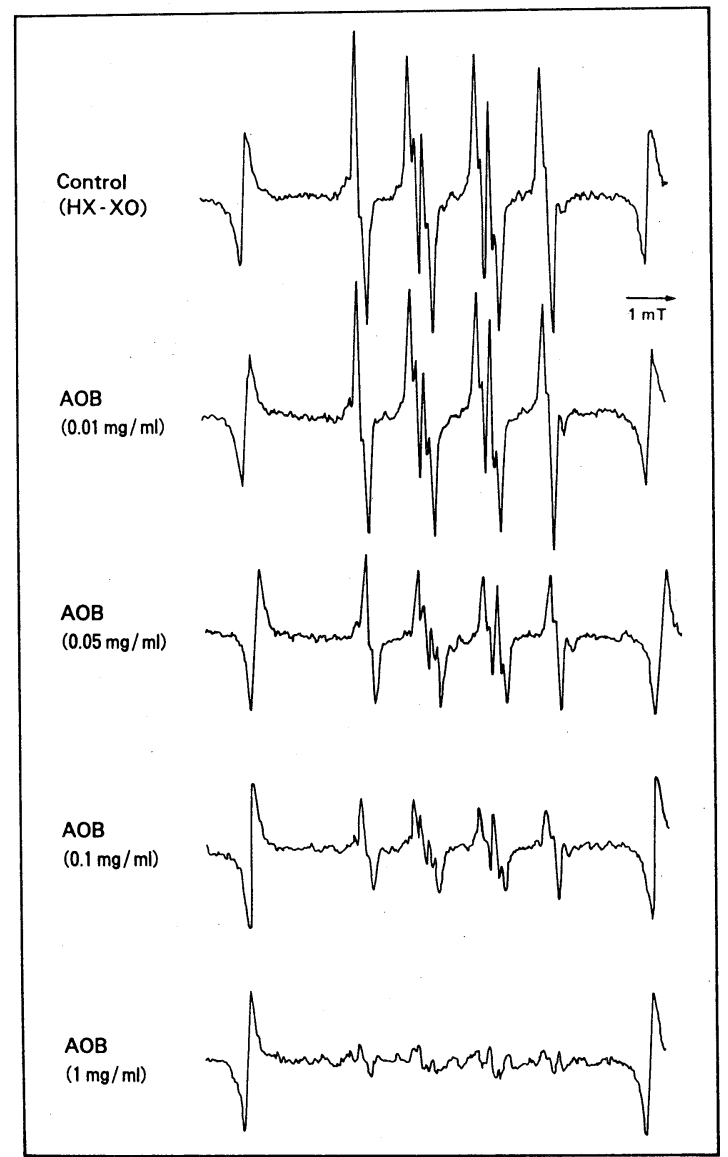

Fig. 1. Scavenging effects of suspension of $\mathrm{AOB}^{\circledR}$ on superoxide radicals generated by hypoxanthine-xanthine oxidase. Reaction mixture contained $0.1 \mathrm{mM}$ hypoxanthine, $0.1 \mathrm{M}$ DMPO, $0.08 \mathrm{U} / \mathrm{ml}$ xanthine oxidase, and $\mathrm{AOB}^{\circledR}$ in $50 \mathrm{mM}$ PBC (pH: 7.4, with $0.1 \mathrm{~mm}$ DTPA).

dose-dependent scavenging activity was observed as $0.103,0.619$, and $1.369 \mathrm{U} / \mathrm{ml}$, respectively. The $\mathrm{IC}_{50}$ was $42 \mu \mathrm{g} / \mathrm{ml}$. All experiments were performed in duplicate. The ESR spectra is shown in Fig. 1.

AOB $^{\circledR}$ reduced the DMPO-OH signal at $1.0 \mathrm{mg} / \mathrm{ml}$. The scavenging activity of AOB $^{\circledR}$ showed $31.1 \mathrm{mU} /$ liter on the inhibition of DMPO-OH signal with $10 \mathrm{~mm}$ DMPO, however, with $100 \mathrm{mM}$ DMPO, it showed $6.61 \mathrm{mU} /$ liter. This result indicates that the inhibition of signal intensity of DMPO-OH is not mediated by competitive inhibition of $\mathrm{AOB}^{\circledR}$ with DMPO, but by the inhibition of Fenton's reaction.

AOB $^{\circledR}$ attenuated the stable free radical DPPH signal in dose-dependent 


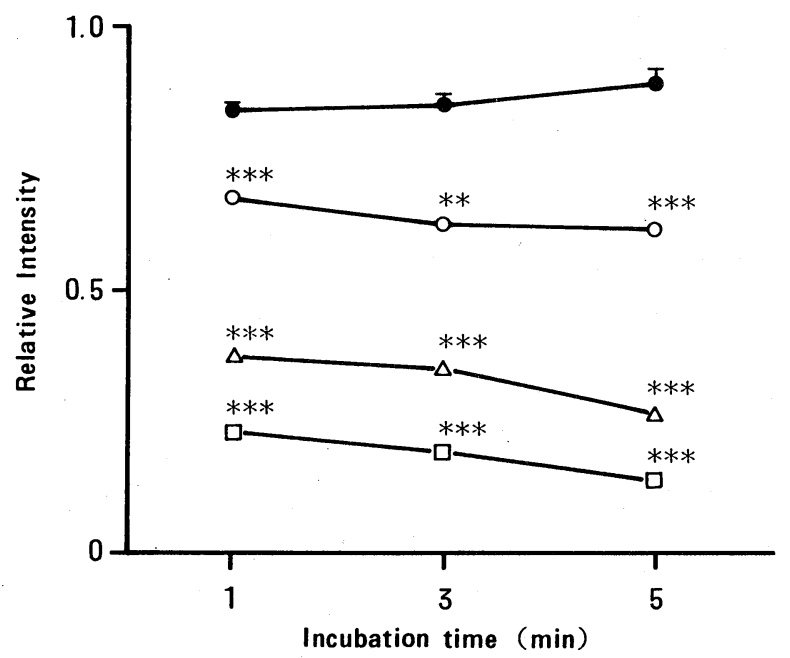

Fig. 2. Scavenging effect of $A O B^{\circledR}$ on DPPH radical. Reaction mixture contained $100 \mu \mathrm{M}$ DPPH and 1,3 , and $5 \mathrm{mg} / \mathrm{ml}$ of $\mathrm{AOB}^{\circledR}$. Measurement was performed after 1,3 , or $5 \mathrm{~min}$ at room temperature. $\bullet$, control; $\bigcirc, 1 \mathrm{mg} / \mathrm{ml} ; \triangle, 3 \mathrm{mg} / \mathrm{ml} ; \square$, $5 \mathrm{mg} / \mathrm{ml}$ of $\mathrm{AOB}^{\circledR}$. Values are $\mathrm{M} \pm \mathrm{SEM}$. $* * p<0.01, * * * p<0.001$ compared with control group. All experiments were performed in triplicate.

manner (Fig. 2). AOB $^{\circledR}$ at 1.0, 3.0, and $5.0 \mathrm{mg} / \mathrm{ml}$ significantly reduced the DPPH radicals $(p<0.001)$.

\section{Test of plasma dilution multiplier}

Since the control plasma contained various substances (e.g., ascorbic acid, uric acid) with superoxide scavenging activity originally, it was impossible to use plasma of 10-fold dilution; that was why it was unsuitable for testing an additional increase in scavenging activity. Even if very low concentration of $\mathbf{A O B}^{\circledR}$ was administered, the superoxide that developed in this system had disappeared almost completely in plasma including $\mathbf{A O B}^{\circledR}$. Consequently, plasma was diluted 4-, 8-, and 12-fold (final dilutions of 40-, 80-, and 120-fold) and a suitable dilution multiplier was determined for use in the experiment. The plasma of rats fed the basal diet exhibited an inhibition rate of $40.8 \pm 2.71 \%$ at a 4-fold dilution, $24.1 \pm 1.99 \%$ at an 8-fold dilution, and $14.0 \pm 4.99 \%$ at a 12 -fold dilution $(n=4-6)$. Thus, we evaluated superoxide scavenging activity at a dilution of 120 -fold, the final concentration with relatively little effect.

\section{$A O B^{\circledR}$ administered for 1 or 3 days}

Rats were fed either $A O B^{\circledR} 1$ or $5 \mathrm{~g} /$ day for $24 \mathrm{~h}$ or for 3 days, and the superoxide scavenging activity was measured in plasma. The superoxide scavenging activity in the plasma of rats fed $\mathrm{AOB}^{\circledR}$ at a dose of $1 \mathrm{~g}$ /day for 1 or 3 days was 
Table 2. Effects of $\mathrm{AOB}^{\circledR}$ on superoxide scavenging activity of rat plasma.

\begin{tabular}{cc}
\hline & $\mathrm{O}_{2}{ }^{-}$scavenging activity $(\mathrm{U} / \mathrm{ml})$ \\
\hline Control (basal diet) $^{\circledR}$ (for 1 day) & $0.15 \pm 0.02$ \\
$\mathrm{AOB}^{\circledR}$ (day & $0.11 \pm 0.03$ \\
$1 \mathrm{~g} /$ day & $0.23 \pm 0.02^{* *}$ \\
$5 \mathrm{~g} /$ day & \\
$\mathrm{AOB}$ & (for 3 days) \\
$1 \mathrm{~g} /$ day & $0.28 \pm 0.04^{* *}$ \\
$5 \mathrm{~g} /$ day & $0.40 \pm 0.06^{* *}$
\end{tabular}

Reaction mixture contained $20 \mu 1$ each of $1 \mathrm{~mm}$ hypoxanthine, $1 \mathrm{M}$ DTPA, $1 \mathrm{M}$ DMPO, $0.8 \mathrm{U} / \mathrm{ml}$ xanthine oxidase, and the 12-fold dilution of plasma to $100 \mu \mathrm{l}$ of $100 \mathrm{mM}$ phosphate-buffered saline (PBS; $\mathrm{pH} 7.4)$. Values are $\mathrm{M} \pm \operatorname{SEM}(n=4-5)$. $*_{p}<0.01$ compared with control group.

$0.110 \pm 0.028(n=5)$ and $0.280 \pm 0.042 \mathrm{U} / \mathrm{ml}(n=5)$, respectively, compared with $0.152 \pm 0.017 \mathrm{U} / \mathrm{ml}(n=5)$ in the controls. Those given $\mathrm{AOB}^{\circledR}$ for 3 days showed a significant rise $(p<0.01)$ in scavenging activity. At the dose of $\mathrm{AOB}^{\circledR}, 5 \mathrm{~g} /$ day, the activity was $0.233 \pm 0.016(n=4)$ and $0.396 \pm 0.057 \mathrm{U} / \mathrm{ml}(n=5)$, respectively. Both groups administered $\mathrm{AOB}^{\circledR}, 5 \mathrm{~g} /$ day for 1 or 3 days, showed a significant increase in plasma superoxide scavenging activity $(p<0.01)$ (Table 2$)$.

Thus, AOB $^{\circledR}$ exhibited significant superoxide scavenging activity following oral administration.

\section{Effect of $A O B^{\circledR}$ on autoxidation of rat brain homogenate}

AOB $^{\circledR}$ inhibited the increase of TBARS in rat brain homogenate after incubation for $1 \mathrm{~h}$ (Fig. 3). The $\mathrm{IC}_{50}$ was $8 \mu \mathrm{g} / \mathrm{ml}$. The time course appears in Fig. 4. For comparison, we studied the inhibitory effect of $\alpha$-tocopherol and ascorbic acid. Thus, $\mathrm{AOB}^{\circledR}$ had a stronger antioxidative effect than either $\alpha$-tocopherol or ascorbic acid (Table 3). Each ingredient of $\mathrm{AOB}^{\circledR}$ before roasting and fermentation, which was soybean, wheat germ, adlay, rice bran, sesame, and green tea, was tested, but these ingredients little inhibited lipid peroxidation (Table 4). These results suggested that it was important to transform each ingredient into low molecular weight substances by roasting and fermentation with $A$. oryzae.

\section{DISCUSSION}

AOB $^{\circledR}$ scavenged superoxide radicals and DPPH radicals, and markedly inhibited lipid peroxidation in rat brain homogenates in vitro. Moreover, $\mathbf{A O B}^{\circledR}$ had a DMPO-OH radical-scavenging action by inhibiting Fenton's reaction. These results indicate that $\mathrm{AOB}^{\circledR}$ is capable of scavenging the oxygen radicals and of inhibiting the propagation of lipid peroxidation. Among the principal ingredients of $\mathrm{AOB}^{\circledR}$ are flavonoids, $\alpha$-tocopherol, ascorbic acid, tannins, catalase, peroxidase, etc. These are known to have antioxidative properties. However, the antioxidant 


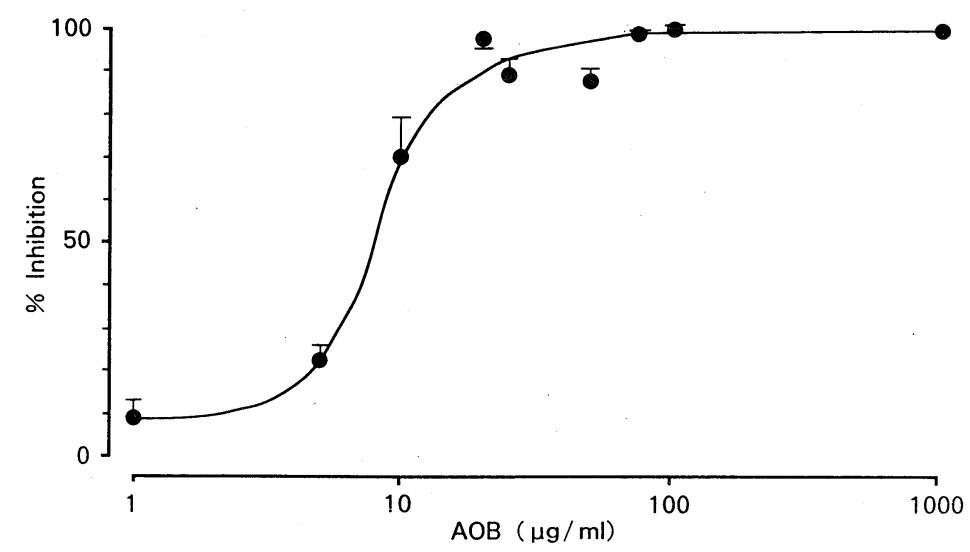

Fig. 3. Inhibitory effect of $\mathrm{AOB}^{\circledR}$ on lipid peroxidation of rat brain homogenate after $1 \mathrm{~h}$ of incubation. Five percent brain homogenate and $\mathbf{A O B}^{\circledR}$ were incubated for $1 \mathrm{~h}$ at $37^{\circ} \mathrm{C}$. Lipid peroxidation was expressed as \% inhibition of the increase of TBA-reactive substances of control. Each point indicates the $\mathrm{M} \pm \mathrm{SEM}$ of 5 experiments. $\mathrm{IC}_{50}=8.0 \mu \mathrm{g} / \mathrm{ml}$ of $\mathrm{AOB}^{\circledR}$.

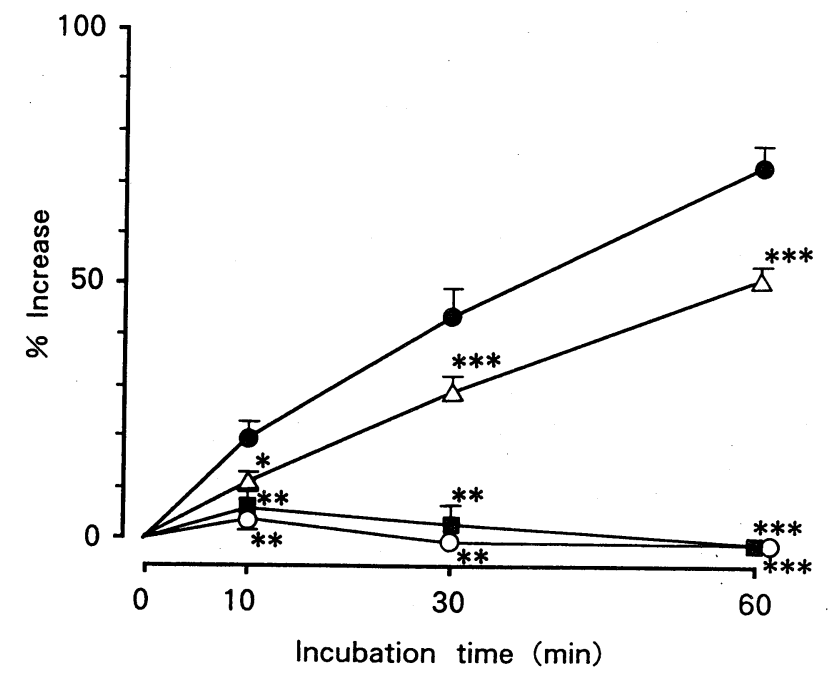

Fig. 4. Inhibitory effect of $\mathrm{AOB}^{\circledR}$ on time course of lipid peroxidation in rat brain homogenate. Values are \% increase of TBA-reactive substances. $\bullet$, control; $\triangle$, $5 \mu \mathrm{g} / \mathrm{ml} ; \mathbf{\square}, 10 \mu \mathrm{g} / \mathrm{ml} ; \bigcirc, 20 \mu \mathrm{g} / \mathrm{ml}$ of $\mathrm{AOB}^{\circledR}$. Each point indicates the $\mathrm{M} \pm \mathrm{SEM}$ of 5 experiments. $*_{p}<0.05, *_{p}<0.01, * * * p<0.001$ compared with control group. 
Table 3. Inhibitory effects of antioxidants on lipid peroxidation.

\begin{tabular}{lc}
\hline & $\mathrm{IC}_{50}(\mu \mathrm{g} / \mathrm{ml})$ \\
\hline AOB $^{\circledR}$ & 8 \\
$\alpha$-Tocopherol & 60 \\
Ascorbic acid & 273 \\
\hline
\end{tabular}

Values are $50 \%$ inhibitory conbcentration $\left(\mathrm{IC}_{50}\right)$ of production of TBA-reactive substances with the control level being $0 \%$ inhibition.

Table 4. Effect of the composition of $\mathrm{AOB}^{\circledR}$ on lipid peroxidation in rat brain homogenate.

\begin{tabular}{lc}
\hline $10 \mu \mathrm{g} / \mathrm{ml}$ & $\%$ inhibition \\
\hline Soybean & $4.6 \pm 3.8$ \\
Wheat germ & $6.6 \pm 1.7$ \\
Adlay & 0 \\
Rice bran & $5.6 \pm 2.4$ \\
Sesame & $4.5 \pm 1.5$ \\
Green tea & $2.8 \pm 4.1$ \\
AOB $^{\circledR}$ & $64.6 \pm 3.7^{*}$ \\
\hline
\end{tabular}

Values are \% inhibition of TBA-reactive substances with the control level being $0 \%$ inhibition. ${ }^{*} p<0.05$ compared with control.

effects of $\mathrm{AOB}^{\circledR}$ were not apparent before roasting and fermentation with $A$. oryzae (Table 4). It is possible that these ingredients are transformed to low molecular weight substances by roasting and fermentation with $A$. oryzae. We determined the superoxide scavenging activity of this healthy food using an ESR spin-trapping method. According to the results of tests made by the Japan Food Analysis Center, $\mathrm{AOB}^{\circledR}$ contains $2.82 \mathrm{mg}$ of ascorbic acid and $0.137 \mathrm{mg} \alpha$-tocopherol per gram. A volume of $\mathrm{AOB}^{\circledR}, 0.01 \mathrm{mg} / \mathrm{ml}$ contained a superoxide scavenging activity of 0.103 $\mathrm{U} / \mathrm{ml}$, which contained $0.03 \mu \mathrm{g} / \mathrm{ml}$ of ascorbic acid. Furthermore, as compared to the control group, the plasma level of ascorbic acid at a dose of $\mathbf{A O B}^{\circledR}$ of $5 \mathrm{~g}$ given for 1 day showed low values (data not shown). When the scavenging activity of L-ascorbic acid was measured in this system with 1,5 , and $10 \mu \mathrm{g} / \mathrm{ml}$ of the superoxide scavenging activity was $0.087,0.924$, and $2.256 \mathrm{U} / \mathrm{ml}$, respectively (data not shown). These findings cannot be attributed solely to the ascorbic acid contained in $\mathbf{A O B}^{\circledR}$. $\mathbf{A O B}^{\circledR}$ markedly prevented lipid peroxidation more than $\alpha$-tocopherol or ascorbic acid did.

In the ESR study, we observed no significant superoxide scavenging activity 1 $\mathrm{h}$ after orally administering $2 \mathrm{~g} / \mathrm{kg}$, or at 1 and $2 \mathrm{~h}$ after orally administering $5 \mathrm{~g} / \mathrm{kg}$ of $\mathrm{AOB}^{\circledR}$ in plasma. However, when the rats were freely allowed to consume $5 \mathrm{~g}$ of $\mathrm{AOB}^{\circledR}$ for $24 \mathrm{~h}$, we noted significant plasma superoxide scavenging activity. Consumption of $\mathrm{AOB}^{\circledR}$ for 3 days led to a much stronger superoxide scavenging activity. These observations suggest that better absorption of $\mathrm{AOB}^{\circledR}$ and stronger 
effect, the scavenging activity will be achieved by consuming small amounts of $\mathrm{AOB}^{\circledR}$ over prolonged periods rather than consuming large quantities at one time. The substances contained $\mathrm{AOB}^{\circledR}$ and its metabolic products with superoxide scavenging activity mentioned above appear to exhibit a strong superoxide scavenging activity as a result of an overall additive and/or synergistic effect.

In conclusion, the commercial health food $\mathbf{A O B}^{\circledR}$ has strong antioxidative properties.

We thank Mr. Fujie of AOA Japan Co., Ltd. for kindly providing us with AOB ${ }^{\circledR}$.

\section{REFERENCES}

1) Pryor, A. W. (Eds.) (1976-1984): Free Radicals in Biology, Vols. I-VI, Academic Press, New York.

2) Simic, G. M., and Karel, M. (Eds.) (1980): Autoxidation in Food and Biological Systems, Plenum Press, New York.

3) Lewis, D. H., and Del Maestro, R. F. (Eds.) (1980): Free radicals in medicine and biology. Acta Physiol. Scand., 492 (Suppl.) pp. 1-168.

4) Rodgers, A. M., and Powers, L. E. (Eds.) (1981): Oxygen and Oxygen Radicals in Chemistry and Biology, Academic Press, New York.

5) Bors, W., Saran, M., and Tait, D. (Eds.) (1984): Oxygen Radicals in Chemistry and Biology, Walter de Gruyter, Berlin.

6) Bannister, V. J., Halliwell, H., and O’Neill, P. (Eds.) (1985): Free Radicals in Biology and Medicine, Harwood, London.

7) Poli, G., Ceeseman, H. K., Dianzani, U. M., and Slater, F. T. (Eds.) (1985): Free Radicals in Liver Injury, IRL Press, Oxford.

8) Halliwell, B., and Gutteridge, C. M. J. (1985): Free Radicals in Biology and Medicine, Clarendon Press, Oxford.

9) Halliwell, B., and Gutteridge, C. M. J. (1985): Free radicals in biology and medicine. Mol. Aspects Med., 8, 89-193.

10) Cohen, G., and Geenwald, A. R. (Eds.) (1983): Oxy Radicals and Their Scavenger Systems, Elsevier Biomedical, New York.

11) McBrien, H. C. D., and Slater, F. T. (Eds.) (1982): Free Radicals, Lipid Peroxidation and Cancer, Academic Press, London.

12) Yagi, K. (Eds.) (1982): Lipid Peroxides in Biology and Medicine, Academic, New York.

13) Sies, H. (Eds.) (1985): Oxidative Stress, Academic Press, London.

14) Sies, H. (1986): Biochemistry of Oxidative Stress. Angew. Chem. Int. Ed. Engl., 25, 1058-1071.

15) Okuda, T., Fujita, Y., Yoshida, T., and Hatano, T. (1990): Suppression of active oxygen by natural products, in Free Radicals in Clinical Medicine, Vol. 4, ed. by Kondo, M., Oyanagui, Y., and Yoshikawa, T., Nihon-Igakukan, Tokyo, pp. 19-30.

16) Namiki, M., and Osawa, T. (1986): Antioxidants/antimutagens in foods, in Antimutagenesis and Anticarcinogenesis Mechanisms, ed. by Shankel, D. M., Hartman, P. E., Kada, T., and Hollaender, A., Plenum Press, New York, pp. 131-142. 
17) Hochstein, P., and Atallah, A. H. (1988): The nature of oxidants and antioxidant systems in the inhibition of mutation and cancer. Mutat. Res., 202, 363-375.

18) Ohkawa, H., Ohnishi, N., and Yagi, K. (1979): Assay for lipid peroxides for animal tissues by thiobarbituric acid reaction. Anal. Biochem., 95, 351-358. 